\title{
PENGGUNAAN INTERNET SEBAGAI MEDIA PEMBELAJARAN PADA MAHASISWA IAIN PALU
}

\section{Hamka}

IAIN Palu Jl. Diponegoro No. 23 Palu Sulawesi Tengah 94221

E-mail: hamxaid@gmail.com

\begin{abstract}
This article is the result of research on the use of the Internet as a medium of learning in students of IAIN Palu. This study used descriptive qualitative approach. The results show: first, use of the Internet as a medium of learning in Palu IAIN can be mapped into three categories, namely: the use of web searching facility, the use of e-mail facilities, and the use of elearning facilities. Secondly, in terms of infrastructure, hardware to support internet-based learning is sufficient, but the amount of bandwidth is still very far from the standard requirements. Meanwhile, in terms of human resources, still need to increase their knowledge and skills in the field of IT for teachers and students to be able to implement an optimal internet-based learning. Third, Palu IAIN students responded very positively to the use of the Internet as a medium of learning.
\end{abstract}

Abstrak. Artikel ini merupakan hasil penelitian tentang penggunaan internet sebagai media pembelajaran pada mahasiswa IAIN Palu. Penelitian ini menggunakan pendekatan kualitatif deskriptif. Hasil penelitian menunjukkan: pertama, penggunaan internet sebagai media pembelajaran di IAIN Palu dapat dipetakan ke dalam tiga kategori, yaitu: penggunaan fasilitas web searching, penggunaan fasilitas e-mail, dan penggunaan fasilitas e-learning. Kedua, dari segi saranaprasarana, hardware untuk menunjang pembelajaran berbasis internet sudah cukup, tetapi besaran bandwidth masih sangat jauh dari standar kebutuhan. Sedangkan, dari segi sumber daya manusia, masih perlu peningkatan pengetahuan dan keterampilan di bidang IT bagi dosen dan mahasiswa untuk dapat menerapkan pembelajaran berbasis internet secara optimal. Ketiga, mahasiswa IAIN Palu memberikan tanggapan yang sangat positif terhadap penggunaan internet sebagai media pembelajaran.

Kata Kunci: Internet, media pembelajaran, E-learning 


\section{PENDAHULUAN}

Kajian tentang internet sebagai media pembelajaran telah banyak dilakukan dalam beberapa tahun terakhir, terutama setelah jaringan internet tersedia di hampir seluruh wilayah Indonesia. Arafah Husna dan Sri Wahyuni, misalnya, telah melakukan penelitian yang berjudul "Kesiapan Jurusan Teknologi Pendidikan dalam Implementasi E-Learning". Penelitian ini memotret bagaimana kesiapan jurusan Teknologi Pendidikan pada Fakultas Ilmu Pendidikan Universitas Negeri Malang dalam menerapkan sistem pembelajaran online yang diformat dalam bentuk e-learning. Hasil penelitiannya menunjukkan bahwa secara umum Jurusan Teknologi Pendidikan UN Malang telah siap menerapkan e-learning, tapi masih perlu terus dikembangkan baik dari segi SDM maupun sarana pendukungnya. ${ }^{1}$

Penelitian senada juga pernah dilakukan oleh Dwi Agung Nugroho Arianto dan Mahfudlah Fajri dengan judul "Penerapan Elearning dalam Program Pembelajaran di Program Pascasarjana IAIN Walisongo Semarang". Penelitian ini mendeskripsikan penggunaan internet sebagai media pembelajaran yang diformat dalam bentuk e-learning pada PPs IAIN Walisongo Semarang. Hasil penelitiannya menunjukkan bahwa terdapat sejumlah kendala dalam penerapan e-learning pada objek penelitian, antara lain: masih kurangnya pemahaman mahasiswa tentang teknologi pembelajaran berbasis internet serta terbatasnya infrastruktur pendukung. ${ }^{2}$

Artikel konseptual berkenaan dengan penggunaan internet sebagai media pembelajaran juga banyak ditemukan, antara lain

${ }^{1}$ Lihat: Arafah Husna dan Sri Wahyuni “Kesiapan Jurusan Teknologi Pendidikan dalam Implementasi E-Learning" dalam Jurnal Penelitian Kependidikan, (Tahun 18, Nomor 1, April 2008), h. 1-20

${ }^{2}$ Lihat: Dwi Agung Nugroho Arianto dan Mahfudlah Fajri "Penerapan Elearning dalam Program Pembelajaran di Program Pascasarjana IAIN Walisongo Semarang"dalamJurnal Seruni FTI UNSA (Volume 1, 2012), h. 502510 
dapat dilihat dalam tulisan Ade Kusmana yang berjudul " $E$ learning dalam Pembelajaran". Beliau berkesimpulan bahwa penggunaan internet sebagai media pembelajaran merupakan suatu keharusan dalam merespon perkembangan teknologi informasi yang berimplikasi terhadap pergeseran paradigma dalam dunia pendidikan saat ini. Teknologi informasi telah menawarkan berbagai kemudahan dalam pembelajaran.Dengan teknologi ini, peserta didik dapat belajar lebih fleksibel dan tidak terhalang oleh keterbatasan ruang dan waktu. ${ }^{3}$

Masih banyak lagi penelitian yang mengkaji tentang penerapan internet dalam dunia pendidikan, khususnya sebagai media pembelajaran. Namun, sepanjang telaah penulis, belum ada yang secara khusus mengkaji tentang penerapan internet sebagai media pembelajaran pada mahasiswa IAIN Palu.

Kondisi real-sehubungan peroalan yang dikaji-yang ditemukan pada pra penelitian menunjukkan bahwa: 1) para dosen IAIN Palu umumnya telah mengikuti pelatihan penggunaan internet dan E-learning dalam pembelajaran; 2) jaringan internet berbasis wifi tersedia di semua jurusan;3) penggunaan internet dan terutama penerapan e-learning belum berjalan secara optimal. Sehingga dalam penelitian ini, penulis mencoba menganalisa dan menjelaskan pola, faktor-faktor yang mempengaruhi serta respon mahasiswa terhadap penggunaan internet sebagai media pembelajaran dan atau penerapan $e^{-}$ learning dalam pembelajaran di IAIN Palu.

\section{KAJIAN TEORI}

Internet merupakan singkatan dari Interconnection Networking. Internet berasal dari bahasa latin "inter"yang berarti antara. Secara kata perkata internet berarti jaringan antara atau penghubung, sehingga kesimpulan dari defenisi

${ }^{3}$ Lihat: Ade Kusuma, "E-learning dalam Pembelajaran" dalam Lentera Pendidikan (Volume 12, No. 1, Juni 2011), h. 35-51 
internet ialah merupakan hubungan antara berbagai jenis komputer dan jaringan di dunia yang berbeda sistem operasi maupun aplikasinya dimana hubungan tersebut memanfaatkan kemajuan komunikasi (telepon dan satelit) yang menggunakan protokol standar dalam berkomunikasi yaitu protokol TCP/IP (Transmission Control/Internet Protocol). ${ }^{4}$

\section{Secara sederhana menurut Purwadi:}

Internet adalah sebuah jaringan komputer yang terdiri dari berbagai ukuran jaringan komputer di seluruh dunia mulai dai PC, jaringanjaringan lokal berskala kecil, jaringan-jaringan kelas menengah, hingga jaringan-jaringan utama yang menjadi tulang punggung internet. ${ }^{5}$

Model koneksi internet itu sendiri dapat dilakukan pada komputer pribadi maupun jaringan LAN/WAN. Defenisi LAN/WAN menurut Nugroho, antara lain:

LAN (Local Area Network) suatu jaringan yang terbentuk dengan menghubungkan beberapa komputer yang berdekatan yang berada pada suatu ruang atau gedung yang terkoneksi ke internet gateway. WAN (Wide Area Network) adalah format jaringan dimana suatu komputer dihubungkan dengan yang lainnya melalui sambungan telepon. Data dikirim dan diterima oleh atau dari suatu komputer ke komputer lainnya lewat sambungan telepon. Konektor komputer dengan telepon adalah menggunakan modem (Modulator, Demodulator). ${ }^{6}$

Perkembangan teknologi Internetworkyang dimulai dari sejarah pendiriannya dan perkembangannya hingga saat ini benar-benar dapat dirasakan sangat bermanfaat dalam setiap aspek kehidupan. Sutedjo memaparkan sejarah masuknya internet di Indonesia, yaitu:

Di Indonesia, jaringan internet mulai dikembangkan pada tahun 1983 di Universitas Indonesia, berupa UInet oleh Dr.Joseph F.P Luhukay yang

${ }^{4}$ Lihat Akhmad Fauzi, PengantarTeknologi Informasi (Yogyakarta:Graha Ilmu, 20008), h. 333-335

${ }^{5}$ Daniel H. Purwadi, Belajar Sendiri Mengenal Internet Jaringan Informasi Dunia (Jakarta: Alex Media Komputindo, 1995), h. 1

${ }^{6}$ Nugroho Adi, Konsep Pengembangan System Basis Data, Informatika (Bandung: t.p., 2008), h. 44 
ketika itu baru saja menamatkan program dokter filosofi ilmu komputer di Amerika Serikat. Jaringan itu dibangun selama empat tahun. Pada tahun yang sama, Luhukay juga mulai mengembangkan University Network (UNInet) dilingkungan Departemen Pendidikan Dan Kebudayaan yang merupakan jaringan komputer dengan jangkauan yang lebih luas yang meliputi Universitas Indonesia, Institut Teknologi Bandung, Institut Pertanian Bogor, Universitas Gajah Mada, Institut Teknologi Surabaya, Universitas Hasanuddin dan Ditjen. ${ }^{7}$

Jaringan internet telah menjadi pelopor terjadinya revolusi teknologi. Internet semakin diminati oleh banyak kalangan baik perorangan maupun instansi-instansi pemerintah ataupun swasta, termasuk diantaranya perpustakaan. Hal-hal yang menyebabkan internet menjadi solusi praktis, sehingga diminati banyak kalangan, antara lain: ${ }^{8}$

- Audien Global

Informasi yang dipublikasikan dalam internet, dengan segera tersedia ke seluruh pengguna audien secara global. Hal inilah yang membuat internet (www) menjadi media yang sangat efektif dari segi pembiayaan untuk mempublikasikan informasi, kurang lebih mencapai hingga 190 negara di seluruh penjuru dunia.

- Operasi Non-Stop

Internet beroperasi non-stop selama 24 jam sehari, hal ini menjadikannya sebagai mesin bisnis yang sangat efisien sekali, sehingga anda tidak perlu lagi menunggu hingga sumber-sumber tersedia untuk menyelenggarakan bisnis anda, karena setiap saat anda dapat menggunakannya.

- Murah

Internet relatif lebih murah dibandingkan media lainnya hanya dengan biaya beberapa ratus ribu saja, anda dapat menampilkan informasi ke seluruh pengguna internet di

${ }^{7}$ Budi Sutedjo, Perencanaan dan Pembangunan System Informasi. (Yogyakarta: Andi Publisher, 2002), h. 52. 2015)

${ }^{8}$ Lihat: http://id.wikipedia.org/wiki/Revolusi_Digital (Diakses 20 April 
dunia. Jelas sekali kalau internet merupakan media yang praktis dengan biaya yang terjangkau (murah).

- Penyebaran Informasi

Ketika informasi ditampilkan kedalam web, saat itu juga siap dinikmati oleh jutaanpengguna yang lain. Misalnya dengan media www, dimana hal ini sangat sulit dilakukan pada dunia nyata.

- Alat Publikasi

Tidak terlalu berlebihan jika internet merupakan suatu alat publikasi yang cukup andal. Sebagaimana diketahui, saat ini banyak sekali aplikasi berbasis internet yang telah dikomersialkan dan mudah sekali didapatkan.

Internet memberikan banyak kemudahan dalam pemanfaatan setiap fasilitas yang disuguhkan untuk di akses pengguna. Fasilitas yang terdapat di internet cukup banyak jenis dan kegunaannya sehingga dapat memberikan dukungan bagi kegiatan akademik, kalangan media massa, praktisi bisnis, keperluan pemerintahan, dan para peneliti. Fasilitas tersebut seperti Telnet, Gopher, Wais, E-mail, Mailing list (milis), Newsgroup, File Transfer Protocol (FTP), Internet Relay Chat, USEnet, Bulletin Board Service (BBS), Internet Telephony, Internet Fax, Layanan Multimedia (WWW).

Di antara fasilitas yang ada di internet tersebut ada lima aplikasi standar internet yang dapat dipergunakan untuk keperluan pendidikan, yaitu:World Wide Web (www),FTP (File Transfer Protocol), E-Mail, Mailing List, News Group ${ }^{9}$

Dari sejumlah fasilitas yang terdapat dalam dunia maya tersebut, menurut Valkenburg dan Soeters, sebagaimana dikutip Rochmawati, penggunaan internet di kalangan pelajar paling

${ }^{9}$ Lihat selengkapnya: Akhmad Fauzi, PengantarTeknologi...., h. 354; Hardjito, "Internet untuk Pembelajaran" dalam Jurnal Teknodik,6 (10), (2002). h. 1 
umum adalah belajar atau mengerjakan PR (73\%), email (59\%), bermain permainan (38\%), situs chat (32\%), dan hobi dan minat (31\%). Dalam pencatatan populer melampaui batas penggunaan, penelitian akademik kualitatif terutama mengambil "teknologi baru untuk domestikasi " pendekatan, berfokus pada bagaimana keluarga menyediakan internet di dalam rumah, mengkontekstualitaskan objek baru ini dari praktek pemakaian di dalam ruang rumah, waktu dan hubungan sosial, dan mengintegrasikannya dalam lingkungan media yang sudah kompleks. ${ }^{10}$

Selanjutnya, untuk mengetahui intensitas pemanfaatan intenet seseorang, menurut Horrigan terdapat dua hal mendasar yang harus diamati, yakni frekuensi internet yang sering digunakan dan lama menggunakan tiap kali mengakses internet yang dilakukan oleh pengguna internet. The Graphic, Visualization \& Usability Center, the Georgia Institute of Technology menggolongkan pengguna internet menjadi tiga kategori dengan berdasarkan pemanfaatan intensitas internet:

- Heavy users, pengguna internet yang menghabiskan waktu lebih dari 40 jam per bulan. Jenis pengguna internet ini adalah salah satu ciri-ciri pengguna internet yang addicted.

- Medium users, pengguna internet yang menghabiskan waktu antara 10 sampai 40 jam per bulan.

- Light users, pengguna internet yang menghabiskan waktu kurang dari 10 jam per bulan. ${ }^{11}$

Pengguna internet yang paling banyak, khususnya di Indonesia, berasal dari kelompok usia SLTA hingga mahasiswa. Hal ini disebabkan oleh fasilitas internet yang menyuguhkan

${ }^{10}$ Weny Rochmawati, "Perilaku Pemanfaatan Internet (Internet Utilization Of Behavior) (Studi Deskriptif tentang Pemanfaatan Internet Untuk Kepentingan Hiburan dan Akademik di Kalangan Anak-Anak di Kota Surabaya)" dalam http://journal. unair.ac.id/detail_jurnal.php?id $=4404 \&$ med $=136 \&$ bid $=8$ (Diakses tanggal 13 April 2015)

${ }^{11}$ Ibid. 
berbagai kebutuhan psikologis kaum muda, bukan saja sebagai sumber informasi dan pengetahuan, tetapi juga sebagai tempat hiburan, media sosial, bisnis dan lain sebagainya.

Model pembelajaran berbasis internettermasuk dalam model pembelajaran yangmasih relatif baru. Karakteristik pembelajaranberbasis internet pun sangat bervariasitergantung pada implementasinya dalam duniapendidikan. Implementasidari pembelajaran berbasis internetsetidaknya ada dua, yaitu: pertama,pembelajaran berbasis internetyangdiselenggarakan secara sederhana, sekedarkumpulan bahan pembelajaran yang dimuatdalam web server dengan tambahan forumkomunikasi lewat e-mail atau milist. Kedua,terpadu melalui portal e-learning yang berisiberbagai obyek pembelajaran yang diperkayadengan multimedia serta dipadukan dengansistem informasi akademik, evaluasi,komunikasi, diskusi dan berbagai educationtools lainnya. Implementasi pembelajaranberbasis internetbisa masuk ke dalamkategori tersebut, yakni bisa terletak diantarakeduanya, atau bahkan bisa merupakangabungan beberapa komponen dari dua sisitersebut. ${ }^{12}$

Meskipun implementasi sistem e-learning yang ada sekarang ini sangat bervariasi, namun semua didasarkan atas suatu prinsip atau konsep bahwa e-learning dimaksudkan sebagai upaya pendistribusian materi pembelajaran melalui media elektronik atau internet sehingga peserta didik dapat mengaksesnya kapan sajadari seluruh penjuru dunia.

Ciri pembelajaran berbasis e-learning adalah terciptanya lingkungan belajar yang flexible dan distributed. Mahasiswa menjadi sangat flexible dalam memilih waktu dan tempat belajar karena mereka tidak harus datang di suatu tempat pada waktu tertentu. Pihak pengajar dapat memperbaharui materi

${ }^{12}$ Surjono, Dwi, Herman, Pengantar Elearningdan Penyiapan Materi, Makalahdiklat dosen FT UNY,http:herman//.elearning-jogja.org, 2008 (diakses 28 Maret 2015). 
pembelajaran kapan saja dan di mana saja. Berdasarkan segi isi, materi pembelajaran pun dapat dibuat sangat flexible mulai dari bahan kuliah yang berbasis teks sampai materi pembelajaran yang saratdengan komponen multimedia. Distributted learning menunjuk pada pembelajaran di mana pengajar, mahasiswa dan materi pembelajaran terletak di lokasi yang berbeda, sehingga mahasiswa dapat belajar kapan saja dan dari mana saja.

Sistem e-learning dapat diimplementasikan dalam bentuk asynchronous, synchronous atau campuran dari keduanya. Contoh e-learning asynchrounous banyak dijumpai di internet baik sederhana maupun terpadu melalui portal e-learning, sedangkan dalam e-learning synchrounous, dosen atau pengajar dan mahasiswa harus berada di depan komputer secara bersamasama karena proses pembelajaran dilaksanakan secara live, baik melalui video maupun audio converence. Pemakaian asynchronous, synchronous secara bersamaan biasa disebut Blended learning, yakni pembelajaran yang menggabungkan semua bentuk pembelajaran misalnya on-line, live, maupun tatap muka. $^{13}$

Berdasarkan definisi dan implementasi pembelajaran berbasis elearning di atas, dapat diketahui karakteristik pembelajaran berbasis elearning sebagai berikut: pertama, memanfaatkan komputer sebagai media pembelajaran. Proses pembelajaran dalam kelas maupun luar kelas melibatkan teknologi elektronik, komputer sebagai salah satu hasil karya dari kemajuan teknologi dapat digunakan menggantikan media yang masih bersifat konvensional. Kedua, memanfaatkan teknologi jaringan komputer, komputer didesain agar dosen dan mahasiswa dapat berinteraksi, diharapkan dapat terjadi proses belajar mengajar seperti proses belajar mengajar dalam kelas. Proses interaksi dalam sebuah komputer yang telah didesain jaringan, juga masih berlaku walaupun proses belajar terjadi dalam kelas,

${ }^{13}$ Ibid. 
mengingat kegiatan proses belajar mengajar dalam kelaspasti membutuhkan komunikasi dua arah antara dosen dan mahasiswa.

Ketiga adalah menggunakan bahan ajar bersifat mandiri (self learning materials) disimpan di komputer sehingga dapat diakses oleh dosen dan mahasiswa kapan saja dan dimana saja bila yang bersangkutan memerlukannya.

Keempat, membutuhkan pembimbing, elearning tetap membutuhkan dosen, bukan menghilangkan dosen ataupun menggantikan peran dosen dalam proses belajar mengajar. Kehadiran e-Learning hanya sebagai media belajar, tidak kurang dan tidak lebih. Penambahan materi ajar dosen bertambah dalam proses mengajar menggunakan elearning, dari dulunya hanya mendidik dan mengajar tentang materi kuliah, sekarang bertambah membimbing mahasiswa dalam pengoperasian elearning.

\section{METODE PENELITIAN}

Penelitian ini bersifat kualitatif, yakni berupaya menghimpun data, mengolah dan menganalisa secara kualitatif dan mendefenisikannya secara kualitatif pula. ${ }^{14}$ Pengumpulan data dilakukan melalui metode: angket, ${ }^{15}$ wawancara mendalam, observasi, dan dokumentasi. Metode-metode ini digunakan secara berbarengan dan saling mendukung satu sama lain.

Data yang diperoleh dianalisis dengan menggunakan Analisis Interaktf Miles dan Huberman. Teknik analisis ini pada

\footnotetext{
${ }^{14}$ Wardi Bachtiar, Metodologi Penelitian Ilmu Dakwah (cet. I; Jakarta: Logos, 1997), h. 21

${ }^{15}$ Pengunaan angket dilakukan untuk memperoleh data-data yang berhubungan dengan tanggapan mahasiswa tentang penggunaan internet sebagai media pembelajaran. Angket juga memuat pertanyaan-pertanyaan yang akan dijadikan starting poin menelusuri data-data yang perlu diperdalam melalui wawancara. Untuk kebutuhan ini, penulis memilih 140 mahasiswa secara acak untuk dijadikan sebagai sampel.
} 
dasarnya terdiri dari 3 komponen yaitu: reduksi data, penyajian data dan penarikan serta pengujian kesimpulan. ${ }^{16}$

\section{HASIL DAN PEMBAHASAN}

\section{Penggunaan Internet sebagai Media Pembelajaran pada Mahasiswa IAIN Palu}

Di kalangan mahasiswa IAIN Palu, yang menjadi objek kajian penelitian ini, penggunaan internet sebagai media pembelajaran dapat diklasifikasikan ke dalam tiga bentuk, yaitu: penggunaan web searching, penggunaan email, dan penggunaane-learning.

\section{Web searching}

Fasilitas web searching di internet merupakan salah satu fasilitas yang paling lazim digunakan oleh para mahasiswa. Hasil angket menunjukkan bahwa 48\% mahasiswa menggunakan internet untuk browsing mencari bahan yang berhubungan dengan materi perkuliahan, 40\% menggunakannya untuk mencari informasi atau berita, dan sisanya, 12\% menggunakannya sekedar sebagai hiburan atau mencari teman.

Bahkan, semua mahasiswa mengakui bahwa sebagian besar tugas-tugas dari dosen diselesaikan dengan bantuan internet $(20 \%$ menyatakan beberapa kali, 16\% kadang-kadang, dan $64 \%$ menyatakan selalu).

Tampaknya, fasilitas web searching di internet memberikan solusi yang mudah bagi mahasiswa untuk menyelesaikan tugastugas perkuliahan yang diberikan oleh dosen, apalagi jika tugastugas tersebut berupa makalah atau resume. Ketika mereka ditanya alasannya, jawaban yang diperoleh adalah: karena praktis (51\%), cepat (34\%), menarik (10\%), dan hanya sebagian kecil (5\%) yang beralasan karena selalu up to date.

${ }^{16}$ Pawito, Penelitian Komunikasi Kualitatif (Yogyakarta: PT. LKiS Pelangi Aksara, 2007), h. 104. 
Data ini menunjukkan bahwa ada kecenderungan mahasiswa menyelesaikan tugas-tugas perkuliahan secara instant melalui bantuan internet, sehingga tidak jarang terjadi praktek plagiasi makalah di kalangan mahasiswa. Internet, dengan demikian, tidak dijadikan sebagai alat bantu untuk mencari informasi terkini yang dapat memperkaya pengetahuan mareka tentang materi perkuliahan, melainkan sebagai sumber "barang jadi" berupa makalah atau resume yang dapat didownload langsung untuk memenuhi kewajiban yang dibebankan oleh dosen. Tidak heran jikamateri yang paling banyak diakses oleh mahasiswa terkait dengan bahan perkuliahan adalah: makalah mahasiswa dari perguruan tinggi lain (70\%), selebihnya Jurnal elektronik (7\%), Buku elektronik (5\%), dan pendapat para blogger (18\%).

Hal ini dipertegas dengan jawaban mahasiswa ketika ditanya tentang sumber utama yang menjadi rujukan dalam mempelajari materi perkuliahan.Sebagian besar dari mereka (73\%) menyatakan bahwa materi perkuliahan mereka pelajari melalui dosen dan buku paket, 20\% menambahkannya dengan buku penunjang lain, dan hanya $7 \%$ yang mencantumkan internet sebagai sumber penunjang dalam mempelajari materi perkuliahan.

Dengan demikian, motiv mahasiswa dalam penggunaan internet sebagai media pembelajaran, bukanlah untuk memperluas wawasan dan memperdalam pengetahuan, tetapi untuk memudahkan mereka dalam menyelesaikan tugas-tugas dari dosen. Tentu lebih praktis mendownload makalah atau resume yang sudah jadi dari internet, dibanding harus ke perpustakaan mencari bahan-bahan dan selanjutnya menyusun makalah sendiri.

Kondisi yang demikian tentu tidak mendidik, bahkan sebaliknya dapat mematikan kreativitas mahasiswa. Tidak jarang ditemukan mahasiswa yang mempresentasikan makalah di kelas 
tetapi tidak memahami isi makalahnya sendiri karena pada dasarnya makalah tersebut bukan hasil kerjanya melainkan hasil kerja orang lain yang didownload dari internet.

Menghadapi masalah ini, perlu strategi yang tepat dari setiap dosen agar mahasiswa dapat menjadikan internet sebagai salah satu media pembelajaran tanpa harus kehilangan kreativitas mereka. Dan yang terpenting, bagaimana membekali mahasiswa dengan kejujuran akademik sejak awal (mahasiswa baru), sehingga praktek plagiasi dari internet tidak membudaya.

\section{E-mail}

Di samping fasilitas web searching yang paling dominan digunakan sebagai media pembelajaran di kalangan mahasiswa IAIN Palu, fasilitas e-mail juga menjadi salah satu media yang digunakan dalam proses pembelajaran. Fasilitas ini biasanya digunakan oleh mahasiswa untuk berkomunikasi dengan dosen. 47\% dari responden menyatakan bahwa mereka biasa berkomunikasi dengan dosen melalui e-mail. Namun, saat ditelusuri lebih lanjut, bentuk komunikasi yang dimaksud masih terbatas pada penyetoran tugas-tugas perkuliahan (makalah) ke alamat e-mail dosen-dosen tertentu.

Di samping itu, tidak semua mahasiswa memiliki alamat email. Terdapat $6 \%$ responden mengaku belum memiliki e-mail, 45\% menyatakan telah memiliki tapi jarang digunakan, dan hanya 49\% menyatakan telah memiliki dan selalu digunakan. Bagi mereka yang belum memiliki e-mail, biasanya menggunakan alamat e-mail temannya, atau alamat e-mail penyedia jasa rental internet apabila ada tugas-tugas yang harus dikirim kepada dosen.

Uraian di atas menunjukkan bahwa, bagi sebagian mahasiswa, memiliki alamat e-mail belumlah menjadi sebuah kebutuhan. Hal ini dapat disebabkan oleh beberapa faktor, antara lain: belum ada penekanan dari dosen agar mahasiswa mengirim 
tugas menggunakan alamat e-mail sendiri, e-mail jarang digunakan sebagai alat komunikasi karena sms dianggap lebih cepat dan memiliki jaringan yang lebih luas (tidak membutuhkan koneksi internet).

\section{E-learning}

Pembelajaran dengan menggunakan fasilitas e-learning belum populer di kalangan mahasiswa IAIN Palu. Data hasil angket menunjukkan hanya $10 \%$ dari responden yang menunjukkan adanya penggunaan e-learning sebagai media pembelajaran.

Dalam e-learning ini terdaftar 322 mahasiswa sebagai pengguna (user), dengan 4 (empat) matakuliah, yaitu: Metode Studi Islam, Komputer dan IT, Teknologi Pembelajaran dan Statistik. Desain e-learning ini cukup sederhana, dengan menggunakan aplikasi claroline. Pada halaman pertama ditampilkan menu login, yang mempersyaratkan para mahasiswa (user) untuk mendaftarkan diri terlebih dahulu, dan setelah mendapat persetujuan dari admin barulah yang bersangkutan dapat masuk dan mengakses mata kuliah yang diinginkan.

Setelah melakukan registrasi dan mendapat persetujuan dari Admin, user (mahasiswa) dapat masuk pada halaman utama e-learning. Langkah selanjutnya adalah memilih mata kuliah yan: akan diikuti, dalam hal ini mata kuliah yang diampuh oleh doses yang bersangkutan sesuai jadwal perkuliahan pada semeste berjalan.

Pada halaman utama ini, mahasiwa dapat memilih mata kuliah dengan cara mengklik icon "mendaftar pada mata kuliah baru". Setelah mendapat persetujuan dari dosen yang bersangkutan/admin, mahasiswa dapat mengakses halaman mata kuliah yang dipilih.

Pada halaman mata kuliah ini terdapat beberapa menu, yaitu: Deskripsi mata kuliah, agenda, pengumuman, dokumen, 
latihan-latihan, alur pembelajaran, assignment (tugas-tugas), forum, kelompok-kelompok, dan diskusi. Saat dibuka halaman mata kuliah, biasanya tampilan "pengumuman" muncul pada layar utama, sehingga mahasiswa langsung dapat mengetahui info terbaru terkait mata kuliah yang bersangkutan, misalnya, tentang tugas-tugas, materi perkuliahan, nilai dan lain-lain.

Mencermati fasilitas yang terdapat pada e-learning yang menggunakan program claroline ini, meski tidak secanggih program e-learning Moodle, menu-menu didalamnya cukup lengkap untuk kebutuhan standar pembelajaran online, mudah diaplikasikan dan program ini juga tidak terlalu berat dari segi data sehingga sangat tepat digunakan sebagai program pembelajaran online di kampus.

\section{Faktor-faktor yang Berpengaruh terhadap Penggunaan Internet sebagai Media Pembelajaran pada Mahasiswa IAIN Palu}

Berdasarkan uraian terdahulu, diketahui bahwa penggunaan internet sebagai media pembelajaran pada mahasiswa IAIN Palu, belum maksimal.Fasilitas internet yang paling banyak digunakan dalam hal ini masih terbatas pada web searching, meski ada beberapa dosen yang sudah menggunakan $e$ mail dalam menerima tugas-tugas dari mahasiswa. Sedangkan pembelajaran dengan menggunakan e-learning masih sangat langka (hanya empatmata kuliah yang secara aktif menggunakan program ini dalam proses pembelajaran).

Minimnya penggunaan internet sebagai media pembelajaran, tentu dipengaruhi oleh banyak hal yang secara garis besarnya dapat dipetakan ke dalam dua kategori utama, yaitu: faktor sarana-prasarana dan faktor sumber daya manusia.

Sarana dan prasarana pendukung penggunaan internet di kampus IAIN Palu terbilang cukup, meski belum memadai ditinjau dari segi kebutuhan pengguna yang begitu luas.Lembaga ini memiliki satu unit yang dikenal dengan ICT (Information and Communication Technology) yang bertanggungjawab penuh 
dalam mengelola sistem informasi dan komunikasi berbasis internet. Tugasnya antara lain, mengelola website kampus serta sistem administrasi akademik (Siakad) online.ICT memiliki gedung tersendiri sebagai ruang kerja para pengelolanya sekaligus sebagai tempat peralatan.Meski gedung ini terlihat masih terlalu kecil untuk ukuran sebuah pusat kendali sistem komunikasi dan teknologi informasi kampus, tetapi sebagai langkah awal gedung ini sudah cukup efektif dalam menjalankan fungsinya.

Menurut pengelola ICT, dari segi hardware, fasilitas internet di kampus IAIN Palu sudah mencukupi, kekurangannya adalah dari segi bandwidthnya yang masih sangat kecil.Dengan besaran bandwidth yang ada saat ini, jangankan untuk memenuhi kebutuhan dosen dan mahasiswa, untuk kebutuhan tenaga administrasi saja masih jauh dari cukup. ${ }^{17}$

Berdasarkan hasil observasi di lapangan, ditemukan bahwa hampir semua ruang perkuliahan (terutama lantai II dan III) di tiap program studi tidak memungkinkan untuk akses jaringan internet, terutama pada jam-jam perkuliahan. Sehingga, bila membutuhkan akses internet, mahasiswa biasanya harus mencari titik-titik tertentu di area kampus yang memiliki signal internet yang baik, misalnya, di depan gedung ICT atau di depan perpustakaan. Bahkan, pada Program Studi Pascasarjana yang memiliki jaringan internet sendiri melalui telkom-speedy, akses internet hanya bisa dilakukan di lantai I.

Di samping ICT, IAIN Palu juga memiliki Unit Pusat Komputer (UPK).Unit Pusat Komputer memiliki satu laboratorium komputer yang dilengkapi dengan 20 unit PC serta jaringan internet tersendiri.Di tempat inilah para mahasiswa dibekali dengan pengetahuan dasar komputer yang terintegrasi dengan materi mata kuliah Komputer pada semester I di tiap program

\footnotetext{
${ }^{17}$ Arif Rahmat, Pengelola ICT IAIN Palu, "Wawancara oleh penulis” Palu: 05 September 2014
} 
studi.Tempat ini juga dijadikan sebagai pusat pelatihan komputer dan IT bagi para dosen secara berkala, biasanya sekali atau dua kali dalam setahun.

Sarana pendukung lainnya bagi penggunaan internet sebagai media pembelajaran adalah tersedianya komputer (laptop) untuk setiap dosen. Program pengadaan laptop bagi para dosen telah direalisasikan secara bertahap dan sudah berjalan lima tahap dalam lima tahun terakhir, sehingga sebagian besar dosen telah memiliki laptop sendiri yang disediakan oleh lembaga.

Namun, salah satu kekurangan yang dirasakan adalah belum tersedianya fasilitas komputer bagi mahasiswa.Sebagian besar mahasiswa belum memiliki komputer.Sedangkan pihak lembaga belum dapat menyediakan komputer umum yang dapat digunakan oleh mahasiswa secara gratis di tiap prodi.Ini merupakan kendala utama dalam penerapan pembelajaran berbasis internet, karena pembelajaran ini mempersyaratkan komputer sebagai fasilitas wajib bagi setiap pesertanya.

Berdasarkan hasil angket diperoleh data bahwa hanya $23 \%$ mahasiswa yang memiliki komputer desk (di rumah), 15\% yang memiliki laptop, dan $62 \%$ yang belum memiliki komputer. Belum lagi dari segi ketersediaan akses internet bagi mahasiswa di luar kampus, karena hanya 5\% mahasiswa yang memiliki modem sendiri, 23\% menggunakan jasa warnet, dan sisanya memilih menggunakan jaringan internet di dalam kampus, baik dengan menggunakan komputer sendiri (26\%), atau komputer teman (46\%). Sungguh ironis, ternyata lebih banyak yang meminjam komputer teman dibanding yang memiliki komputer sendiri.Kondisi ini tentu sangat menyulitkan bagi kemungkinan penerapan internet sebagai media pembelajaran.

Faktor lain yang sangat berpengaruh terhadap penggunaan internet sebagai media pembelajaran adalah sumber daya manusia, baik dosen maupun mahasiswa. Peningkatan SDM dosen 
dibidang ICT telah dilakukan melalui pelatihan-pelatihan, baik yang dilakukan oleh Unit Pusat Komputer, maupun oleh Lembaga Penjaminan Mutu (LPM). Hingga saat ini, sebagian besar dosen telah menerima pelatihan di bidang penggunaan IT dalam pembelajaran, khususnya tentang e-learning melalui kegiatan Pelatihan Keterampilan Intstruksional (Pekerti) dan Applied Approach (AA). Sehingga secara teoritis, para dosen sebenarnya telah siap dalam mempraktekkan penggunaan internet sebagai media pembelajaran.

Meski demikian, karena program pelatihan ini tidak langsung diaplikasikan dalam praktek perkuliahan, sebagian besar dosen sudah tidak cakap dalam menggunakan program pembelajaran online (e-learning). Banyak alasan mengapa dosen tidak menggunakannya, antara lain, seperti diungkapkan oleh salah seorang dosen IAIN Palu:

Pembelajaran berbasis internet tidak mudah dilakukan karena kondisi mahasiswa kita yang beragam, sebagian besar dari mereka belum memiliki komputer apalagi fasilitas akses internet. Dikhawatirkan hal ini akan memberatkan mahasiswa, terutama bagi mereka dari kalangan ekonomi lemah. ${ }^{18}$

Secara umum, sumber daya mahasiswa dalam pemanfaatan internet sebagai media pembelajaran masih sangat terbatas. Seperti telah diuraikan sebelumnya, fasilitas internet yang paling banyak digunakan masih sebatas web searching, sedangkan untuk penggunaan e-learning tentu membutuhkan pelatihan khusus. Salah seorang dosen memberi tanggapan terkait tidak diterapkannya pembelajaran berbasis internet pada mahasiswa, bahwa:

Untuk penerapan model pembelajaran berbasis internet seperti elearning, dibutuhkan keterampilan dalam mengaplikasikan e-learning itu sendiri.Para dosen telah dilatih melalui PEKERTI dan AA, tapi mahasiswanya sendiri belum pernah dilatih. Sehingga jika dosen akan menerapkannya, minimal dia harus menyisihkan 3 pertemuan awal

\footnotetext{
${ }^{18}$ Kasmiati, Dosen IAIN Palu, “Wawancara oleh Penulis”, Palu: 25 April 2015
} 
pada matakuliahnya khusus untuk melatih mahasiswa menggunakan program ini, dan itu harus dilakukan dengan sarana pendukung yang memadai. Hal ini tentu sulit dilakukan karena akan menyita jam perkuliahan itu sendiri, di samping sarana pendukungnya yang minim. ${ }^{19}$

Oleh karena itu, untuk penggunaan internet sebagai media pembelajaran, perlu dilakukan pelatihan bagi para mahasiswa.Seyogyanya, para mahasiswa telah dibekali dengan pengetahuan dan keterampilan di bidang IT sejak dini, misalnya, dirangkaikan dengan kegiatan OPAK bagi mahasiswa baru. Materinya mencakup hal-hal yang berhubungan dengan pembelajaran berbasis internet, seperti pengenalan website yang bermuatan pendidikan (jurnal online, ebook, dll.), penggunaan perpustakaan digital, penggunaan program e-learning, dll.

Faktor lain yang tak kalah pentingnya dalam penggunaan internet sebagai media pembelajaran adalah tenaga teknis di bidang ICT. IAIN Palu masih sangat kekurangan tenaga teknis di bidang ICT. Bahkan, hingga saat ini belum ada tim khusus yang menangani program e-learning, padahal program ini membutuhkan minimal seorang admin yang bertugas mengelola proses pembelajaran online ini. ${ }^{20}$

Oleh karena itu, perlu kerja sama pihak LPM-sebagai penanggung jawab peningkatan mutu pendidikan di kampusdengan pihak ICT dalam menangani persoalan ini. LPM sebaiknya membentuk tim pengelola e-learning sedangkan persoalan teknis yang berhubungan fasilitas hardware dan softwarenya ditangani oleh ICT. Sehingga tidak seluruhnya dibebankan kepada ICT, apalagi persoalan pembelajaran online membutuhkan admin yang sebaiknya berasal dari tenaga pengajar.

Berdasarkan uraian di atas, dapat dipahami bahwa faktorfaktor yang berpengaruh terhadap penerapan internet sebagai

\footnotetext{
${ }^{19}$ Muhammad Nur Asmawi, Dosen IAIN Palu, "Wawancara oleh Penulis", Palu: 25 April 2015

${ }^{20}$ Arif Rahmat, Pengelola ICT IAIN Palu, "Wawancara oleh penulis" Palu: 05 Maret 2015
} 
media pembelajaran yang meliputi sarana-prasarana, serta SDM dosen, mahasiswa dan tenaga teknis, saling terkait erat satu sama lain.

Dari segi sarana-prasarana, misalnya, kecilnya bandwidth yang dimiliki serta tidak mamadainya fasilitas komputer bagi mahasiswa, membuat dosen enggan menerapkan pembelajaran berbasis internet karena dikhawatirkan akan membebani mahasiswa. Di samping itu, dari segi SDM, para mahasiswa belum dibekali secara memadai dengan keterampilan menggunakan IT sebagai media pembelajaran. Di sisi lain, belum adanya tim khusus yang mengelola pembelajaran online ini, sehingga program elearning yang sudah diaktifkan pada halaman web kampus menjadi mati suri, yang pada akhirnya memaksa pihak ICT untuk menon-aktifkannya.

Jika lembaga berkomitmen untuk menggunakan internet sebagai salah satu media pembelajaran, maka persoalan-persoalan tersebut di atas harus ditangani secara terencana, sistematis dan komprehensif. Memang, pembelajaran berbasis internet adalah sebuah sistem yang di dalam melibatkan banyak faktor yang penangannya tidak bisa dilakukan secara parsial, karena satu faktor saja yang terabaikan, maka sistem ini tidak akan berjalan.

\section{Tanggapan Mahasiswa IAIN Palu tentang Penggunaan Internet sebagai Media Pembelajaran}

Internet sebagai media pembelajaran, bukan lagi hal baru saat ini. Beberapa perguruan tinggi terkemuka bahkan berlomba untuk menjadikan lembaganya sebagai lembaga pendidikan yang berbasis internet. Sehingga, wacana tentang transformasi model pembelajaran ke era digital dan online, sudah menjadi trend di dunia pendidikan.

Bagi kalangan mahasiswa, internet sudah menjadi kebutuhan, bukan sekedar menjadi sumber informasi, tetapi juga sebagai ajang sosialisasi. Sehingga ketika internet dijadikan 
sebagai media pembelajaran, hal itu bukan hal yang mengagetkan bagi mereka. Media ini sudah sangat akrab dengan mahasiswa dalam keseharian mereka.

Tanggapan mahasiswa tentang penggunaan internet sebagai media pembelajaran sangat positif. $81 \%$ responden menyatakan sangat setuju dengan penggunaan internet sebagai media pembelajaran, 13\% menyatakan kurang setuju dan hanya $6 \%$ yang menyatakan tidak setuju. Besarnya minat mahasiswa terhadap penggunaan internet sebagai media pembelajaran juga tergambar pada alokasi waktu yang mereka gunakan dalam mengakses internet untuk kebutuhan perkuliahan. 21\% responden menghabiskan waktu lebih dari 2 jam sehari untuk mencari informasi mengenai tugas-tugas perkuliahan mereka, $20 \%$ menghabiskan waktu di atas 1 jam sehari, 56\% menghabiskan waktu rata-rata 1 jam sehari, dan hanya 3\% yang menyatakan kurang dari 1 jam sehari. ${ }^{21}$

Dengan demikian, berdasarkan standar intensitas penggunaan internet The Graphic, Visualization \& Usability Center, the Georgia Institute of Technology, sebagaimana diungkapkan pada bab II terdahulu, mahasiswa IAIN Palu sebagian besar masuk kategori Medium users, yakni pengguna internet yang menghabiskan waktu antara 10 sampai 40 jam per bulan.

Masih adanya mahasiswa yang kurang setuju bahkan tidak setuju dengan penggunaan internet sebagai media pembelajaran, tampaknya lebih banyak disebabkan oleh faktor biaya. 19\% responden menyatakan bahwa biaya akses internet sangat menyulitkan mereka secara finansial, 68\% menyatakan cukup

\footnotetext{
${ }^{21}$ Dari segi waktu yang paling sering digunakan oleh mahasiswa untuk mengakses internet diperoleh data sebagai berikut: $5 \%$ pagi dan siang hari, $17 \%$ siang dan sore hari, $63 \%$ sore dan malam hari, dan $15 \%$ tidak konsisten dalam satu waktu tertentu, tetapi kapan saja dibutuhkan pagi, siang, sore atau malam hari.
} 
menyulitkan, dan hanya $13 \%$ yang menyatakan tidak menyulitkan. ${ }^{22}$

Variasi jawaban responden ini tentu sangat dipengaruhi oleh latar belakang ekonomi keluarga mereka. Apalagi bagi mereka yang tidak memiliki komputer sendiri, mereka harus menggunakan jasa rental internet dengan biaya yang tidak sedikit.

Mencermati besarnya minat mahasiswa dalam hal penggunaan internet sebagai media pembelajaran di satu sisi, dan keterbatasan mereka dari aspek pembiayaan di sisi lain, maka solusi terbaik adalah menyediakan akses internet gratis bagi mahasiswa, sehingga mereka memiliki lebih banyak kesempatan untuk mengakses internet di kampus tanpa harus ke warnet. Dan akan lebih bagus lagi kalau di setiap program studi disediakan fasilitas komputer umum yang dapat digunakan oleh mahasiswa yang belum memiliki komputer pribadi.

Di samping itu, penambahan kapasitas bandwidth internet dalam kampus harus ditingkatkan. Seperti telah diuraikan terdahulu, bahwa kapasitas bandwidth kampus masih sangat rendah sehingga tidak mampu memberikan pelayanan maksimal bagi kebutuhan warga kampus, terutama mahasiswa. Terkait dengan persoalan ini, 32\% responden berpandangan bahwa jaringan internet di kampus sudah cukup memadai, sedangkan 63\% menyatakan kurang memadai, bahkan terdapat 5\% responden yang menyatakan sangat tidak memadai.

Peningkatan mutu pelayanan internet kampus akan sangat berpengaruh bagi pengembangan media pembelajaran berbasis internet. Hal ini terutama karena mahasiswa lebih banyak mengakses internet di dalam kampus (67\%), dari pada di rumah mereka sendiri (5\%) atau di warnet (23\%).

\footnotetext{
${ }^{22}$ Bahkan terdapat $13 \%$ responden mengaku sering tidak dapat mengakses internet pada saat mereka sangat membutuhkannya karena alasan biaya.
} 
Demikianlah, secara umum mahasiswa memberikan respon positif terhadap penggunaan internet sebagai media pembelajaran. Model pembelajaran ini memiliki prospek yang sangat baik di masa-masa yang akan datang manakala kendalakendala yang dihadapi-sebagaimana telah diuraikan-dapat diselesaikan.

\section{PENUTUP}

Berdasarkan uraian sebelumnya, berikut ini dipaparkan beberapa kesimpulan penelitian.Pertama, penggunaan internet sebagai media pembelajaran di IAIN Palu dapat dipetakan ke dalam tiga kategori: penggunaan fasilitas web searching, penggunaan fasilitas e-mail, dan penggunaan fasilitas e-learning. Dari tiga kategori tersebut, yang paling dominan digunakan masih kategori pertama, web searching. Mahasiswa banyak menggunakan fasilitas ini dalam meyelesaikan tugas-tugas perkuliahan mereka, terutama dalam bentuk makalah dan atau resume. Sedangkan penggunaan e-mail umumnya hanya digunakan untuk mengumpulkan tugas-tugas kepada dosen yang kebetulan mempersyaratkan untuk itu, dan model ini pun tidak banyak yang menerapkannya. Selanjutnya, fasilitas e-learning paling sedikit digunakan, dalam hal ini hanya satu kasus yang ditemukan.

Kedua, secara garis besarnya, faktor-faktor yang berpengaruh terhadap penggunaan internet sebagai media pembelajaran di IAIN Palu, ada dua, yaitu: sarana-prasarana dan sumber daya manusia. Dari segi sarana-prasarana, aspek hardware yang dimiliki oleh ICT sudah cukup, tetapi besaran bandwidth yang dimiliki masih sangat jauh dari standar kebutuhan. Selanjutnya, dari segi sumber daya manusia, masih perlu peningkatan pengetahuan dan keterampilan di bidang IT bagi dosen dan mahasiswa untuk dapat menerapkan pembelajaran berbasis internet secara optimal. 
Ketiga, mahasiswa IAIN Palu memberikan tanggapan yang sangat positif terhadap penggunaan internet sebagai media pembelajaran. Meski demikian, di sisi lain mereka masih mengeluhkan persoalan besarnya biaya yang harus ditanggung, terutama bagi mereka yang belum memiliki komputer sendiri dan atau akses internet pribadi, sementara jaringan internet di kampus masih sangat terbatas.

\section{DAFTAR PUSTAKA}

Adi,Nugroho, Konsep Pengembangan System Basis Data, Informatika, Bandung: t.p., 2008.

Arianto, Dwi Agung Nugroho dan Mahfudlah Fajri "Penerapan Elearning dalam Program Pembelajaran di Program Pascasarjana IAIN Walisongo Semarang"dalamJurnal Seruni FTI UNSA (Volume 1, 2012), h. 502-510

Bachtiar, Wardi, Metodologi Penelitian Ilmu Dakwah, cet. I; Jakarta: Logos, 1997

Fauzi, Akhmad, PengantarTeknologi Informasi, Yogyakarta:Graha Ilmu, 2008

Hardjito, "Internet untuk Pembelajaran" dalam Jurnal Teknodik,6 (10), (2002). h. 1

http://id.wikipedia.org/wiki/Revolusi_Digital (Diakses 20 April 2015

Husna, Arafah dan Sri Wahyuni “Kesiapan Jurusan Teknologi Pendidikan dalam Implementasi E-Learning"dalam Jurnal Penelitian Kependidikan, Tahun 18, Nomor 1, (April 2008), h. $1-20$

Kusuma, Ade, "E-learning dalam Pembelajaran" dalam Lentera Pendidikan, Volume 12, No. 1, (Juni 2011), h. 35-51

Pawito, Penelitian Komunikasi Kualitatif, Yogyakarta: PT. LKiS Pelangi Aksara, 2007

Purwadi,Daniel H., Belajar Sendiri Mengenal Internet Jaringan Informasi Dunia,Jakarta: Alex Media Komputindo, 1995. 
Rochmawati,Weny, "Perilaku Pemanfaatan Internet (Internet Utilization of Behavior) (Studi Deskriptif tentang Pemanfaatan Internet Untuk Kepentingan Hiburan dan Akademik di Kalangan Anak-Anak di Kota Surabaya)" dalam http://journal. unair.ac.id/detail_jurnal.php?id =4404\&med $=136 \&$ bid $=8$ (Diakses tanggal 13 April 2015)

Surjono, Dwi, Herman, Pengantar Elearningdan Penyiapan Materi, Makalahdiklat dosen FT UNY,http:herman//.elearningjogja.org, 2008 (diakses 28 Maret 2015)

Sutedjo, Budi, Perencanaan dan Pembangunan System Informasi, Yogyakarta: Andi Publisher, 2002. 